\title{
Response of Pheretima Posthuma and Some Soil Fertility Enhancing Bacteria to the Copper Stress
}

\author{
Meneka Chetri ${ }^{1}$, Shuvasish Roy Choudhury ${ }^{1}$, Aniruddha Sen ${ }^{2}$ \\ ${ }^{1}$ Department of Zoology, Karimganj College, Karimganj, Assam, India \\ ${ }^{2}$ Biotechnology Hub, Karimganj College, Karimganj, Assam, India
}

Email address:

src_adonis@yahoo.co.in (S. R. Choudhury)

To cite this article:

Meneka Chetri, Shuvasish Roy Choudhury, Aniruddha Sen. Response of Pheretima Posthuma and Some Soil Fertility Enhancing Bacteria to the Copper Stress. International Journal of Biomedical Science and Engineering. Vol. 5, No. 2, 2017, pp. 14-17.

doi: $10.11648 / j . i j b s e .20170502 .11$

Received: December 19, 2016; Accepted: January 11, 2017; Published: March 15, 2017

\begin{abstract}
Physiological or biological stress is an organism's response to a stressor such as an environmental condition or a stimulus. Stress is a body's method of reacting to a challenge. Toxic metals are now everywhere, and affect everyone on planet earth. They have become a major cause of illness, aging and even genetic defects. Copper is essential for the function of most living organisms. But increased concentrations of copper in soils are harmful to soil organisms. Most microorganisms are known to have specific genes for resistance to stress due to heavy metals. Some of the bacteria are resistant to heavy metals and some have attained adaptation towards the toxic effects of the metals. It is also found that soils containing significant copper residues are stressful for earthworms and have been observed to have few earthworms. From the present study also, it was seen that, copper is a stressful factor for soil bacteria and earthworms and both the organisms are affected from the experimental concentrations of Copper.
\end{abstract}

Keywords: Stress, Copper Toxicity, Bacteria, Earthworm, Karimganj, Heavy Metal, Soil

\section{Introduction}

The body's way to respond to stress is by sympathetic nervous system activation which results in the fight-or-flight response. But as the body cannot keep this state for long periods of time, the parasympathetic system returns the body's physiological conditions to normal (homeostasis). Metal toxicity or metal poisoning is the toxic effect of certain metals in certain forms and doses on life. Some metals are toxic when they form poisonous soluble compounds and all heavy metals are particularly not toxic also, and some are even essential such as iron and some, such as bismuth, have a low toxicity.

However, some forms of the required minerals can be highly toxic. Examples are some forms of copper, iron, manganese, hexavalent chromium, selenium and others. Too much of even the most needed minerals can also become toxic. Toxic metals replace nutrient minerals in enzyme binding sites. When this occurs, the metals inhibit, over stimulate or otherwise alter thousands of enzymes.
Copper is not only a ubiquitous metal in the technological environment, it is also essential for the function of most living organisms. Copper ions are required as cofactors by many enzymes, such as oxidases and hydroxylases, but are highly toxic when present in excess. Inside the cells, copper may be bound by various compounds to form copper complexes [1]. Copper is an essential element and required by all organisms. However, elevated concentrations of copper in soils are toxic and stressful and may result in a range of effects including reduced biological activity and subsequent loss of fertility [2].

Effects can occur at relatively low Copper concentrations and influence a number of soil processes including microbial activity, earthworm activity and bio-turbation. In most soils, copper residues are likely to remain indefinitely, and will continue to influence the health of the soil. Soils contain an extremely diverse array of microorganisms including bacteria, fungi, yeasts; photosynthetic organisms including algae, and macro-organisms such as protozoa, nematodes, mites, springtails, spiders, insects and earthworms. The functions of this complex array of biota, often referred to as 
the 'soil food web,' are diverse, and include residue decomposition, nutrient storage and release, soil structure and stability, resistance against disease and degradation or immobilization of pesticides and other pollutants.

Most microorganisms are known to have specific genes for resistance to stress due to heavy metals. Mostly, the resistance genes are found on plasmids or on chromosomes. Bacteria that are resistant to heavy metals also play an important role in biogeochemical cycling of those metal ions [3]. Thus, it is worthwhile to note that although some heavy metals are important and essential trace elements and others are stressful at high concentrations to microbes, some microbes have adapted to tolerate the presence of metals or even to use them to grow. Copper is an essential micronutrient and are used for redox-processes, to stabilize molecules through electrostatic interactions, as components of various enzymes, and for regulation of osmotic pressure [4].

Earthworms have been suggested as useful indicators of soil health $[5,6]$. Soils that contain significant copper residues are stressful for earthworms and have been observed to have few earthworms [7, 8], reduced surface activity (fewer castings visible at the soil surface) and greater litter build-up [9]. At sites in a study on avocado orchards in northern NSW [10], an absence of earthworms in areas of copper contamination was accompanied by a thick layer of organic matter (ca. 10-30 cm deep) that was clearly stratified on the soil surface, with little evidence of breakdown and incorporation into the sub-surface layers. This phenomenon is not seen in other sub-tropical horticultural systems where copper fungicides are not used. In 1983, Ma \& co-workers observed a strong correlation between soil-copper concentration and the level of copper in earthworm tissues. Salminen and Haimialso observed in 2001 that the enchytraeid worm Cognettiasphagnetorum (Oligochaeta) actively avoid copper contaminated soil.

Hence we planned our project work to screen the stress tolerance level of Copper in some soil organisms like soil bacteria and earthworms.

\section{Materials and Method}

\subsection{Isolation of Bacteria and Earthworms}

Soil samples were collected from undisturbed semi forest areas of Karimganj (Shyamaprasad Road), Assam, India in sterile plastic bags and brought to the laboratory. Earthworms were also collected from the same spot. $1 \mathrm{~g}$ of soil was added to $100 \mathrm{ml}$ of sterile distilled water making a dilution of $10^{-2}$. From this, $1 \mathrm{ml}$ was taken by pipette and added to $9 \mathrm{ml}$ of sterile distilled water making a dilution of $10^{-3}$. Following this technique a dilution upto $10^{-5}$ was prepared and $1 \mathrm{ml}$ of the diluted soil sample from the concentration of $10^{-5}$ and $10^{-}$ 4 were plated in Nutrient Agar plates and incubated at $28 \pm 2{ }^{\circ} \mathrm{C}$ for $24 \mathrm{~h}$. After $24 \mathrm{~h}$, the plates were observed for any microbial growth and the microbial colonies were isolated and subcultured thrice subsequently for obtaining pure cultures. These pure cultures were used for the screening. $24 \mathrm{~h}$ old bacterial inoculation grown in liquid culture (Nutrient broth) was used for the study. The earthworms were kept in glass beakers with soil until further use.

\subsection{Screening of Copper Stress Tolerance Level}

\subsubsection{Bacteria}

Nutrient Agar (Himedia) added with $\mathrm{CuSO}_{4}$ solution at the concentration of $0.5 \mathrm{mg} / \mathrm{ml}, 0.75 \mathrm{mg} / \mathrm{ml}, 1 \mathrm{mg} / \mathrm{ml}, 1.25 \mathrm{mg} / \mathrm{ml}$ were prepared autoclaved and then plated in sterilized petridises and allowed to solidify. On solidification, the plates were marked into several small squares on the backside and bacterial inoculum was spotted (spot test) in individual squares and numbered according to the samples spotted. After $1 / 2 \mathrm{~h}$, the plates were sealed with parafilm and then incubated for $48 \mathrm{hrs}$ in inverted position at $28 \pm 2^{\circ} \mathrm{C}$ in an incubator. After the incubation period, the plates were checked for growth of bacteria and the data was tabulated [11].

\subsubsection{Earthworm}

$200 \mathrm{~g}$ of soil sample was dried in oven at $100^{\circ} \mathrm{C}$ for $24 \mathrm{~h}$ and the moisture content was found by the formula

$$
\mathrm{MF}=(\mathrm{I}-\mathrm{F}) /[\mathrm{A}-(\mathrm{I}-\mathrm{F})] \mathrm{X} 100
$$

Where,

$\mathrm{I}=$ Initial wet weightof soil taken+weight of petridish $(\mathrm{g})$

$\mathrm{F}=$ Final dry weight of soil+weight of petridish $(\mathrm{g})$

$\mathrm{A}=$ Initial weight of soil taken $(\mathrm{g})$

Then, $200 \mathrm{~g}$ of soil sample was hydrated with requisite amount of water containing $\mathrm{CuSO}_{4}$ at the concentration of $0.5 \mathrm{mg} / \mathrm{ml}, 0.75 \mathrm{mg} / \mathrm{ml}, 1 \mathrm{mg} / \mathrm{ml}, 1.25 \mathrm{mg} / \mathrm{ml}$ in separate glass beakersupto $45 \%$ ofthe soil moisture. The amount of $\mathrm{CuSO}_{4}$ solution to be added to the dried soil sample was found out by the following formulas

$$
\mathrm{H}=\mathrm{T}-\mathrm{MF}
$$

$\mathrm{H}=$ Hydrataion needed $(\%)$

$\mathrm{T}=$ Target moisture content

$\mathrm{MF}=$ Initial moisture fraction of the soil sample.

$$
\mathrm{W}=(\mathrm{BxH} / 100) \mathrm{XC}
$$

$\mathrm{W}=$ Amount of water to be added

$\mathrm{H}=$ Hydration needed (from ii)

$\mathrm{C}=$ Conversion factor $(1 \mathrm{ml} / \mathrm{g})$

5 earthworms were then inoculated in each beaker and allowed to stay for 14 days. After 14 days, the soil samples were emptied in trays to check out the number of earthworms, study the morphological changes and weight of the surviving earthworms (Norton, 1996). 


\section{Results}

Table 1. Responses of the bacteria against different concentration of $\mathrm{CuSO} 4$.

\begin{tabular}{|c|c|c|c|c|c|}
\hline Isolate number & $0.25 \mathrm{mg} / \mathrm{ml}$ & $0.5 \mathrm{mg} / \mathrm{ml}$ & $0.75 \mathrm{mg} / \mathrm{ml}$ & $1 \mathrm{mg} / \mathrm{ml}$ & $1.25 \mathrm{mg} / \mathrm{ml}$ \\
\hline 1 & + & - & - & - & - \\
\hline 2 & + & - & - & - & - \\
\hline 3 & + & - & - & - & - \\
\hline 4 & + & - & - & - & - \\
\hline 5 & - & - & - & - & - \\
\hline 6 & + & - & - & - & - \\
\hline 7 & + & - & - & - & - \\
\hline 8 & - & - & - & - & - \\
\hline 9 & + & - & - & - & - \\
\hline 10 & - & - & - & - & - \\
\hline 11 & + & - & - & - & - \\
\hline 12 & - & - & - & - & - \\
\hline 13 & + & - & - & - & - \\
\hline 14 & + & - & - & - & - \\
\hline 15 & - & - & - & - & - \\
\hline 16 & + & - & - & - & - \\
\hline 17 & + & - & - & - & - \\
\hline 18 & + & - & - & - & - \\
\hline 19 & + & - & - & - & - \\
\hline 20 & + & - & - & - & - \\
\hline 21 & - & - & - & - & - \\
\hline 22 & + & - & - & - & - \\
\hline 23 & - & - & - & - & - \\
\hline 24 & - & - & - & - & - \\
\hline 25 & - & - & - & - & - \\
\hline 26 & - & - & - & - & - \\
\hline 27 & + & + & + & - & - \\
\hline 28 & + & + & + & - & - \\
\hline 29 & + & + & + & - & - \\
\hline 30 & + & + & + & - & - \\
\hline 31 & + & + & + & - & - \\
\hline
\end{tabular}

Table 2. Responses of the earthworm against different concentration of $\mathrm{CuSO}$.

\begin{tabular}{lllllll}
\hline $\begin{array}{l}\text { Concentration } \\
(\mathbf{m g} / \mathbf{m l})\end{array}$ & $\begin{array}{l}\text { Soil moisture } \\
(\%)\end{array}$ & $\begin{array}{l}\text { Initial Number } \\
\text { of worms }\end{array}$ & $\begin{array}{l}\text { Initial weight } \\
\text { of worms } \mathbf{( g )}\end{array}$ & $\begin{array}{l}\text { Final number } \\
\text { of live worms }\end{array}$ & $\begin{array}{l}\text { Final weight } \\
\text { of worms }(\mathbf{g})\end{array}$ & Morphological changes \\
\hline $0.5 \mathrm{mg} / \mathrm{ml}$ & 45 & 5 & 25 & 5 & 24 & $\begin{array}{l}\text { Shrinkage, paleness } \\
\text { Shrinkage, paleness }\end{array}$ \\
$0.75 \mathrm{mg} / \mathrm{ml}$ & 45 & 5 & 24 & 5 & 21 & $\begin{array}{l}\text { 2 earthworms were found dead. Remaining } \\
\text { earthworms were shrunk and became thin. } \\
1.0 \mathrm{mg} / \mathrm{ml}\end{array}$ \\
\hline 5 & 5 & 27 & 3 & 20 & $\begin{array}{l}\text { 4 earthworms were found dead and remaining } \\
\text { one became pale, shrank etc. }\end{array}$ \\
\hline $01.25 \mathrm{mg} / \mathrm{ml}$ & 45 & 5 & 24 & 1 & 5 & \\
\hline
\end{tabular}

\section{Discussion}

Copper $(\mathrm{Cu})$ is an essential nutrient for plant and microbial growth, but because only a small amount is needed, it is classified as a micronutrient. Copper promotes seed production and formation, plays an essential role in chlorophyll formation and is essential for proper enzyme activity. But due to high use of Copper-fungicides and release of toxic industrial effluents to the environment, the level of Copper is increasing and may cause severe damage to ecosystems including plants, animals, microorganisms and human health $[12,13]$. Copper toxicity damage plant roots, with symptoms ranging from disruption of the root cuticle and reduced root hair proliferation, to severe deformation of root structure. Moreover excessive copper is detrimental to the growth and survivability of microbes and earthworms because it proves to be stressful and hence toxic to them and kills the life forms.

In the present work also, it was seen that maximum number of bacterial isolates could not grow at the concentration of $0.75 \mathrm{mg} / \mathrm{ml}$ of Copper. At $1 \mathrm{mg} / \mathrm{ml}$ concentration, only two bacterial colonies were found to grow. Almost every microbial metabolic activity can be adversely stressful by elevated heavy and toxic metal concentrations Heavy metal resistant microbes are of particular importance because if they are found to possess growth promotory activities towards plants, can be used for polluted land reclamation. In the present study two bacterial isolates were found to grow in high copper concentrations which are a new breakthrough on the studies involving metal toxicity and microorganisms. These bacterial strains will be further studied to screen their metal tolerance level using higher concentration of the salts used in the present study and 
steps would be taken to identify these strains and study their other plant growth promoting activities.

In case of earthworm as well, it was seen that the mortality rate of earthworms increased gradually with the rise in copper concentration and at $1.25 \mathrm{mg} / \mathrm{ml}$ of Copper, only two earthworms could survive, though they showed high variations in their morphology like shrinkage, paleness etc. High copper kills the earthworm [14]. Moreover, high copper gets accumulated in the body of the earthworms rendering the entrance of the toxic heavy metal in food chain as well [15] In the present study also, high dose of copper is stressful and killed the earthworms and made them sick. Further studies with the earthworms which could survive such a high concentration of copper, like finding out the amount of copper absorbed in the tissue, more exposure of the earthworms to further high concentration of copper etc can lead to an insight on the mechanism of adaptability of the earthworms to tolerate the metal stress or screening out some new variants which can survive in contaminated soil and act as bio-fertilizer and may prove useful to determine if the stress level of Copper concentration can pose any change in the physiology of soil bacteria and earthworms.

\section{Conclusion}

It can thus be concluded from the above that high dose of Copper proves to be highly stressful for the soil micro- and macro biota. The bacteria and earthworms used in the present study were killed by the levels of Copper used in the present study. Thus it is a high time for thoughtful use of copper in agricultural fields in order to reduce copper stress.

\section{References}

[1] Nies, DH. Microbial heavy-metal resistance. Appl. Microbiol. Biotchnol. 1999; 51: 730-750.

[2] Dumestre, JF., Guezennec, 1C., Galy, R., Delmas, S., Richard and Labroue. Influence of light intensity on methanotrophic bacterial activity in Petit Saut Reservoir, French Guiana. Appl. Environ. Microbial. 1999; 65: 534-539.

[3] Spain, A. Implications of microbial heavy metal tolerance in the environment. Rev. Undergrad. Res., 2003; 2: 1-6.

[4] Bruins, MR. Kapil, S., Oehme, FW. Microbial resistance to metals in the environment. Ecotoxicol and Environ Safety. 2000; 45, 198-207.
[5] deBruyn LAR. The status of soil macrofauna as indicators of soil health to monitor the sustainability of Australian agricultural soils. Ecological Economics. 1997; 23, 167-178.

[6] Paoletti MG, Sommaggio D, Favretto MR, Petruzzelli G, Pezzarossa B, Barbafieri M (1998) Earthworms as useful bioindicators of agroecosystem sustainability in orchards and vineyards with different inputs. Applied Soil Ecology 10, 137150.

[7] Van Rhee JA. Development of earthworm populations in orchard soils. In: Graff O, Satchell J, editors. Progress in Soil Biology. North Holland Publishing Company, Amsterdam, Netherlands, 1967; 360-371.

[8] Van Zwieten M., Stovold G., Van Zwieten L. Literature Review and Inventory of Alternatives to Copper for Disease Control in the Australian Organic Industry. A report for the Rural Industries Research and Development Corporation. RIRDC Project. 2004b; DAN-208A. ISBN 073471590 0, $101 \mathrm{p}$.

[9] Ma W-C. Sub lethal toxic effects of copper on growth, reproduction and litter breakdown activity in the earthworm Lumbricusrubellus, with observations on the influence of temperature and soil pH. Environmental Pollution. 1984; 33, 207-219.

[10] Merrington G., Rogers SL., Van Zwieten L. The potential impact of long-term copper fungicide usage on soil microbial biomass and microbial activity in an avocado orchard. Australian Journal of Soil Research. 2002; 40, 749-759.

[11] Samanta A., Bera P., Khatun M., Sinha C., Pal P., Lalee A., Mandal A. An investigation on heavy metal tolerance and antibiotic resistance properties of bacterial starin Bacillus sp. isolated from municipal waste. Journal of Microbiology and Biotechnology Reasearch. 2012; 1: 178-189.

[12] Kim H., Wu X., Lee J. SLC31 (CTR) family of copper transporters in health and disease. Molecular Aspects of Medicine. 2013; 34: 561-570.

[13] Wong MH. Ecological restoration of mine degraded soils, with emphasis on metal contaminated soils. Chemosphere. 2003; 50: 775-780.

[14] Bruno Streit. Effects of high copper concentrations on soil invertebrates (earthworms and oribatid mites). Oecologia. 1984; 64, (3), 381-388.

[15] Hunter, A., Johnson, M. S., 1982. Food chain relationship of copper and cadmium in contaminated grassland ecosystems. Oikos 38, 108-117. 